\title{
Analysis of Heavy Metal Content in Fried Foods Wrapped in Black Plastic as a Fried Food Wrap
}

\author{
Fathor Rahman, Nia Sari, \\ Indasah \\ Indonesia \\ Email: \\ radiaterahman@gmail.com
}

Received: March 12, 2019

Accepted : October 13, 2019

Published : November 26, 2019

\begin{abstract}
Fried foods or weci are also called Ote-ote. Ote-ote is a type of fried food which is usually more wrapped in black plastic, where the plastic contains the presence of heavy metal $\mathrm{Pb}$. So this study aims to analyze the effect of heavy metal content $(\mathrm{Pb})$ using new cooking oil and used cooking oil on fried food processing with a hot temperature of $800 \mathrm{C}$, moderate temperature of $450 \mathrm{C}$, and cold temperature of $250 \mathrm{C}$ with a 10 minute wrapping time. This study uses a Randomized Block Design (RBD) method, the sampling technique is carried out by Random Sampling with a sample of 30 consisting of fried foods and oil. Data analysis techniques used the Two Factorial Anova test and Duncan's Test. Independent variables examined include cooking oil and wrapping methods with a hot temperature of $80^{\circ} \mathrm{C}$, medium temperature of $45^{\circ} \mathrm{C}$, and cold temperatures of $25^{\circ} \mathrm{C}$ with a packing time of 10 minutes. The results of the research in the Laboratory showed that the heavy metal content of $\mathrm{Pb}$ in fried foods wrapped in the highest black plastic with a hot temperature of $800 \mathrm{C}$ was an average of $0.881 \mathrm{ppm}$, while the lowest in the average control was $0.294 \mathrm{ppm}$ in the treatment of used oil. In the new oil treatment, the highest metal content of $\mathrm{Pb}$ weight was $0.428 \mathrm{ppm}$, while the lowest in the control was $0.173 \mathrm{ppm}$. From the results of the Two Factorial Anova test that the interaction between oil and wrapping temperature there is an influence on $\mathrm{Pb}$ levels in fried foods with a significant value of $<0.05$, this means that there are interactions in all types of fried food treatment.

Fried foods that experience $\mathrm{Pb}$ contamination cause food to not meet the requirements, this is because the wrapping process uses black plastic with different temperature treatments, where the more hot fried food is packaged, the more $\mathrm{Pb}$ content in fried foods, when food enters the body through blood flow will inhibit the cell's metabolic system, one of which is inhibiting $\mathrm{Hb}$ synthesis in the bone marrow which results in poor cognitive development, a weakened immune system accompanied by symptoms of autism and even death.
\end{abstract}

Keywords: New Oil, Used Oil, Frying Temperature, Black Plastic and $\mathrm{Pb}$ (Lead)

\section{(2) (1) ( $)$}

This is an open-acces article distributed under the terms of the Creative Commons Attribution-ShareAlike 4.0 International License. 


\section{INTRODUCTION}

Processed food is a source of energy for humans and is an essential factor for human growth and development. Packaging is a process of packaging, packaging or packing a product using certain materials so that the products inside can be protected, while product packaging is part of the packaging of a product. While the packaging objectives include to maintain and guarantee the level of health of foodstuffs (BPOM 2013). Packaging materials must have conditions including not toxic and must guarantee sanitation and health factors.

This detrimental factor is an element of destroying food so that food is not safe for consumption. Broadly speaking, the interaction of food products with their packaging includes the transfer of packaging components into food Riani TF, dkk 2014. The transfer of chemical compounds from packaging materials can have an impact on food safety and quality. The interaction between packaging and packaged food raises concerns about the possibility of long-term health effects for someone who consumes these chemicals.

The danger posed by plastic is the possibility of heavy metal contamination that already exists on plastic, so that it can damage food products and cause disease. Another danger is that the plastic used contains monomers from vinyl chloride. Besides the basic material in the form of a monomer, in plastic there is also a non-plastic material called additives needed to improve the properties of the plastic itself. The additive is in the form of low molecular weight substances, which can function as dyes, antioxidants, ultraviolet light absorbers, anti-stick. (Koswara 2016)

The problem that arises is the extent to which lead monomers from the use of food packaging bags originating from plastic move or are included in packaged food, especially if the food is processed using heat and oil, because heat can accelerate the transfer of lead monomers into packed food, Mohammad 2017. This study aims to analyze $\mathrm{Pb}$ levels by using new cooking oil and used cooking oil in the packaging process of fried food with a hot temperature of $800 \mathrm{C}$, medium temperature $450 \mathrm{C}$, and cold temperature of $250 \mathrm{C}$ in 10 minutes contact time.

\section{MATERIALS AND METHODS}

This study was an experimental study using Randomized Block Design (RBD) method, the population in this study was all fried food sellers in Pakong Subdistrict, Pamekasan Regency. The sampling technique is carried out by Random Sampling with a sample of 30 consisting of fried foods and oil. The independent variables in this study were cooking oil and packaging methods. While the dependent variable in this study is the Pb level in fried foods. Data collected through laboratory testing were then analyzed using the Two Factorial Anova test and Duncan's Test.

\section{RESULT}

Distribution of characteristics of heavy metal fried food $\mathrm{Pb}$ wrapped in black plastic using New Cooking Oil

Table 4.1 Heavy Metal Content of Fried Food Pb Wrapped in Black Plastic Using New Oil

\begin{tabular}{|c|c|c|c|c|c|c|c|}
\hline \multirow[t]{2}{*}{ Treatment } & \multirow[t]{2}{*}{ Packing } & \multirow{2}{*}{$\begin{array}{l}\text { Length of } \\
\text { Contact }\end{array}$} & \multicolumn{3}{|c|}{$\begin{array}{l}\text { Heavy Metal Content } \\
\qquad(\mathrm{Pb})\end{array}$} & \multirow[t]{2}{*}{$\begin{array}{l}\text { Total } \\
\text { (ppm) }\end{array}$} & \multirow[t]{2}{*}{$\begin{array}{c}\text { Average } \\
(\mathrm{ppm})\end{array}$} \\
\hline & & & 1 & 2 & 3 & & \\
\hline \multirow{4}{*}{$\begin{array}{c}\text { New } \\
\text { Fried Oil }\end{array}$} & $\begin{array}{c}\text { Hot temperature } \\
80{ }^{\circ} \mathrm{C}\end{array}$ & 10 Minute & 0,429 & 0,428 & 0,429 & 1,286 & 0,428 \\
\hline & $\begin{array}{c}\text { Medium } \\
\text { Temperature } \\
45^{\circ} \mathrm{C}\end{array}$ & 10 Minute & 0,420 & 0,418 & 0,420 & 1,258 & 0,419 \\
\hline & $\begin{array}{c}\text { Cold temperature } \\
25{ }^{0} \mathrm{C}\end{array}$ & 10 Minute & 0,389 & 0,389 & 0,387 & 1,165 & 0,388 \\
\hline & Control & & 0,174 & 0,172 & 0,174 & 0,520 & 0,173 \\
\hline
\end{tabular}

Based on Table 4.1 above shows that the treatment of food packaging ote which uses new cooking oil with a hot temperature of $800 \mathrm{C}$ and 10 minutes of contact time the average $\mathrm{Pb}$ content is $0.428 \mathrm{ppm}$, the temperature is $450 \mathrm{C}$ and the contact time is 10 minutes the average content $\mathrm{The} \mathrm{Pb}$ is $0.419 \mathrm{ppm}$, 
the cold temperature is $250 \mathrm{C}$ and the contact time is 10 minutes, the average $\mathrm{Pb}$ content is $0.388 \mathrm{ppm}$, while the average $\mathrm{Pb}$ content control is $0.173 \mathrm{ppm}$

Distribution of characteristics of heavy metal fried food $\mathrm{Pb}$ wrapped in black plastic using used cooking oil

Table 4.2 Heavy Metal Content of Fried Food Pb Wrapped in Black Plastic Using Used Oil

\begin{tabular}{|c|c|c|c|c|c|c|c|}
\hline \multirow{2}{*}{ Treatment } & \multirow{2}{*}{ Packing } & \multirow{2}{*}{$\begin{array}{l}\text { Length of } \\
\text { Contact }\end{array}$} & \multicolumn{3}{|c|}{$\begin{array}{l}\text { Heavy Metal Content } \\
\qquad(\mathrm{Pb})\end{array}$} & \multirow[t]{2}{*}{$\begin{array}{l}\text { Total } \\
(\mathrm{ppm})\end{array}$} & \multirow[t]{2}{*}{$\begin{array}{c}\text { Average } \\
(\mathrm{ppm})\end{array}$} \\
\hline & & & 1 & 2 & 3 & & \\
\hline \multirow{4}{*}{$\begin{array}{l}\text { Used Fry } \\
\quad \text { Oil }\end{array}$} & $\begin{array}{c}\text { Hot temperature } \\
80^{\circ} \mathrm{C}\end{array}$ & 10 Minute & 0,883 & 0,880 & 0,882 & 2,645 & 0,881 \\
\hline & $\begin{array}{l}\text { Medium } \\
\text { Temperature } \\
45^{\circ} \mathrm{C}\end{array}$ & 10 Minute & 0,848 & 0,848 & 0,847 & 2,543 & 0,847 \\
\hline & $\begin{array}{c}\text { Cold temperature } \\
25^{\circ} \mathrm{C}\end{array}$ & 10 Minute & 0,727 & 0,725 & 0,727 & 2,179 & 0,726 \\
\hline & Control & & 0,295 & 0,293 & 0,294 & 0,882 & 0,294 \\
\hline
\end{tabular}

Based on Table 4.1 above shows that the treatment of food packaging ote which uses used cooking oil with a hot temperature of $800 \mathrm{C}$ and 10 minutes of contact time the average $\mathrm{Pb}$ content is $0.881 \mathrm{ppm}$, the temperature is $450 \mathrm{C}$ and the contact time is 10 minutes the average content $\mathrm{The} \mathrm{Pb}$ is $0.847 \mathrm{ppm}$, the cold temperature is $250 \mathrm{C}$ and the contact time is 10 minutes, the average $\mathrm{Pb}$ content is $0.726 \mathrm{ppm}$, while the average $\mathrm{Pb}$ content is $0.294 \mathrm{ppm}$.

\section{Characteristic distribution of $\mathbf{P b}$ heavy metals in oil}

Table 4.3 Heavy Metal Pb Content in Oil

\begin{tabular}{ccccccc}
\hline \multirow{2}{*}{ No } & \multirow{2}{*}{ Treatment of Oil Type } & \multicolumn{3}{c}{ Pb content } & \multirow{2}{*}{ Total (ppm) } & Average (ppm) \\
\cline { 3 - 5 } & New Oil & I & II & III & & \\
\hline 1 & 0,165 & 0,163 & 0,163 & 0,491 & 0,163 \\
\hline 2 & Used Oil & 0,275 & 0,274 & 0,273 & 0,822 & 0,274 \\
\hline & Total & 0,44 & 0,437 & 0,436 & 1,313 & 0,4376 \\
\hline
\end{tabular}

From the table above shows that the content of heavy metals $(\mathrm{Pb})$ in new cooking oil with an average of $0.163 \mathrm{ppm}$ while in used cooking oil with an average of $0.274 \mathrm{ppm}$, so the use of oil used contains the presence of heavy metals lead $(\mathrm{Pb})$ and not feasible for making frying ingredients, this is because that the $\mathrm{Pb}$ content in oil and the $\mathrm{Pb}$ content in plastic will accumulate $\mathrm{Pb}$ content in these fried foods 
Distribution of the influence of heavy metal fried food $\mathrm{Pb}$ wrapped in black plastic using new cooking oil and used oil

Diagram: 4.2 Transfer of Pb Heavy Metals in Black Plastics and Oils to Ote-Ote Fried Foods

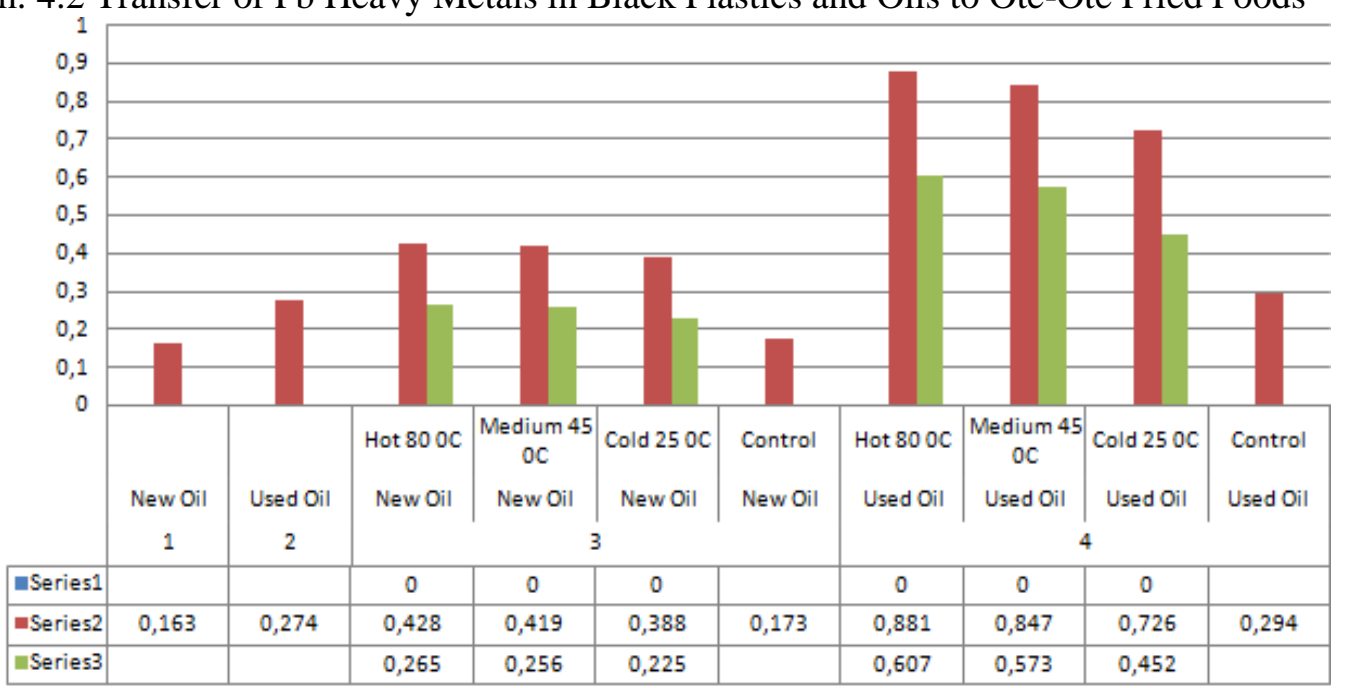

Ket: Blue color is the time of flowering, Red PB in food while Green $\mathrm{Pb}$ is in plastic

The content of $\mathrm{Pb}$ in new cooking oil is $0.163 \mathrm{ppm}$ while in used oil is $0.274 \mathrm{ppm}$. From the diagram above, it can be explained that the addition of $\mathrm{Pb}$ into fried foods with the black plastic packaging process is.

1. The content of $\mathrm{Pb}$ in ote-ote food in the process of frying new oil with a hot temperature of $800 \mathrm{C}$ using black plastic as a food wrap in 10 minutes on average is $0.428 \mathrm{ppm}$, the temperature is $450 \mathrm{C}$ on average $0.419 \mathrm{ppm}$, cold temperature $250 \mathrm{C}$ averages $0.388 \mathrm{ppm}$ and the average control is $0.173 \mathrm{ppm}$. Whereas the migration of black plastic as food pembusus from $800 \mathrm{C}$ hot temperature was $0.265 \mathrm{ppm}$, the temperature was $450 \mathrm{C}$ on average $0.256 \mathrm{ppm}$, the cold temperature was $250 \mathrm{C}$ on average $0.225 \mathrm{ppm}$.

2. The content of $\mathrm{Pb}$ in food ote-ote in the process of frying oil used with a hot temperature of $800 \mathrm{C}$ using black plastic as a food wrap in 10 minutes on average by $0.881 \mathrm{ppm}$, the temperature is $450 \mathrm{C}$ on average $0.847 \mathrm{ppm}$, cold temperature $250 \mathrm{C}$ averages $0.726 \mathrm{ppm}$ and the average control is $0.294 \mathrm{ppm}$. Whereas the migration of black plastic as food pembusus from $800 \mathrm{C}$ heat temperature was $0.607 \mathrm{ppm}$, the temperature was $450 \mathrm{C}$ on average $0.573 \mathrm{ppm}$, the cold temperature was $250 \mathrm{C}$ on average $0.425 \mathrm{ppm}$

\section{DISCUSSION}

Pb Levels in Fried Foods Wrapped in Black Plastic in Hot Temperatures of 80 0C, Medium Temperatures of $45 \mathrm{0C}$, and Cold Temperatures of $25 \mathrm{0C}$ for 10 Minutes of Contact Using New Cooking Oil.

From the results of research conducted in the laboratory, it can be seen that the content of $\mathrm{Pb}$ in ote-ote food in the process of frying new oil with a hot temperature of $80 \mathrm{C}$ using black plastic as a food wrap in 10 minutes on average is $0.428 \mathrm{ppm}$, the temperature is $450 \mathrm{C}$ an average of $0.419 \mathrm{ppm}$, a cold temperature of $250 \mathrm{C}$ averaging $0.388 \mathrm{ppm}$ and an average control of $0.173 \mathrm{ppm}$. Whereas the migration of black plastic as food pembusus from $800 \mathrm{C}$ hot temperature was $0.265 \mathrm{ppm}$, the temperature was 45 $0 \mathrm{C}$ on average $0.256 \mathrm{ppm}$, the cold temperature was $250 \mathrm{C}$ on average $0.225 \mathrm{ppm}$.

Plastics are widely used as packaging such as fried food wrappers. Behind its practical and easy nature, black plastic contains dangerous chemicals that can contaminate food in it. The hazardous chemicals are among the first stages of dyestuff formation while the second is in the PVC stage (Plastic Polyvinyl Chloride), PVC is made from vinyl chloride monomer (VCM). Vinyl chloride monomers that do not react but can be released into food, especially those that are greasy or fatty or contain alcohol especially 
in hot conditions. In the manufacture of PVC as a stabilizer, such as lead $(\mathrm{Pb})$, kadium $(\mathrm{Cd})$, lead $(\mathrm{Cn})$ or other, to prevent damage to PVC, (Chairunnisa, 2013).

The migration of these chemicals has an impact in the form of a decrease in food quality and food safety, also has an effect on health. The number of migrated compounds is generally not known with certainty, but can be fatal especially in the long term (cumulative and carcinogenic).

Pb Levels in Fried Foods Wrapped in Black Plastic in Hot Temperatures of 80 0C, Moderate Temperatures of $45 \mathrm{0C}$, and Cold Temperatures of $250 \mathrm{C}$ For 10 Minutes of Contact Using Used Cooking Oil.

Examination results in the laboratory The content of $\mathrm{Pb}$ in ote-ote food in the process of frying used oil with a hot temperature of $800 \mathrm{C}$ using black plastic as a food wrap in 10 minutes averaged $0.881 \mathrm{ppm}$, the temperature was $450 \mathrm{C}$ on average $0.847 \mathrm{ppm}$, temperature cold $250 \mathrm{C}$ on average 0.726 $\mathrm{ppm}$ and control on average $0.294 \mathrm{ppm}$. Whereas the migration of black plastic as food pembusus from $800 \mathrm{C}$ heat temperature was $0.607 \mathrm{ppm}$, the temperature was $450 \mathrm{C}$ on average $0.573 \mathrm{ppm}$, the cold temperature was $250 \mathrm{C}$ on average $0.425 \mathrm{ppm}$.

Factors affecting migration are the type of chemical concentration contained, the nature and composition of food, temperature and quality of packaging materials (if the material is inert or not easy to react, the migration potential is small and vice versa).

The migration of toxic substances is a serious long-term problem for the health of consumers, therefore special attention is needed in the selection of food packaging. Responding to the existence of types of packaging materials that easily immigrate into food products, special policies are needed that are effective and achieve the goals in packaging selection.

\section{$\mathrm{Pb}$ content in new oil and used oil used by fried fried food sellers}

Laboratory examination results showed that lead $(\mathrm{Pb})$ levels in new oil samples before frying contained an average lead content of $0.163 \mathrm{ppm}$, while in used oil after laboratory examination, the lead content was 0.274 so that the category was very poor according to SNI and the regulation of the Head of the Republic of Indonesia Drug and Food Supervisory Agency Number HK.00.06.1.52.4011 in 2009 which is because it exceeds the specified threshold of $0.121 \mathrm{ppm}$.

Basically the use of used cooking oil or repeated times is not good because it causes the higher content of heavy metals $(\mathrm{Pb})$ in oil, what if viewed from its chemical composition, cooking oil repeatedly contains compounds that are carcinogenic which are formed during the frying process

Menurut Novianti K. 2014 Factors that can trigger oxidation include heat, light, metal Weight Pb, alkaline atmosphere, degree of unsaturation, pigment and oxygen. Using this reaction principle, short chain hydrocarbons in fatty acids that cause unpleasant odors can be exchanged with long, non-volatile chains. Ketaren, 2015

\section{The Effect of Use of New Cooking Oil and Used Cooking Oil on Fried Foods Wrapped in Black Plastic Against the Content of $\mathrm{Pb}$ at Hot Temperatures of $80 \mathrm{C}$, Moderate Temperature of $45 \mathrm{C}$, and Cold Temperature of $25 \mathrm{CC}$ for 10 Minutes of Contact.}

From the results of the two factorial ANOVA tests in the table above it can be concluded that: Types of oil in fried foods. There is an interaction between these two factors, indicating there is a real influence with the value of Sig. 0,000<0,05 Packaging temperatures for fried foods. There is an interaction between these two factors, indicating there is a real influence with the value of Sig. 0,000 $<0,05$ Type of oil and packaging temperature for fried foods There is an interaction between these two factors, indicating there is a real influence with the value of Sig. $0,000<0,05$

Basically the packaging process that uses black plastic as a food wrapper is not safe for consumption because it exceeds the threshold that has been determined by SNI that is $0.1 \mathrm{mg} / \mathrm{kg}$. Lead compounds that enter the body through ote-ote food averaged $4.159 \mathrm{ppm}$, whereas normal lead that enters the human body is approximately $0.3 \mathrm{mg}$. For normal people with input of $0.6 \mathrm{mg}$ of lead per day for a long time can be poisoned. Entry of lead with a greater level of $0.6 \mathrm{mg}$ per day accelerates the accumulation and incidence of poisoning, for example by the entry of $25 \mathrm{mg}$ of lead per day of poisoning occurs after 4 years while $4,159 \mathrm{mg}$ per day only takes a few months. Absorbed lead approximately $40 \%$ of the smoke from lead oxide inhaled is absorbed in the breathing. In the bloodstream, most of the lead is absorbed in the form of bonds with erythrocytes (Ladauda 2012). Lead can choke the oxidase 
enzyme and consequently inhibit the cell's metabolic system, one of which is inhibiting Hb synthesis in the bone marrow. Lead inhibits sulfidryl enzymes to bind delta amnolevulinic acid (ALA) to porprobilinogen, and protophorevirin IX to $\mathrm{Hb}$. This causes anemia and the presence of basophilic stipling retention of ribosomal DNA in the cytoplasm of erythrocytes thereby disrupting protein synthesis. After exposure to stop the lead levels will decrease over a period of half-life of lead in the blood approximately 2-4 weeks later.

\section{CONCLUSION}

The average $\mathrm{Pb}$ content in oil is $0.1636 \mathrm{ppm}$ and used oil used by fried fried food sellers is 0.274 ppm on average. Of the two oils used by fried food sellers, it is not suitable to use because it exceeds the threshold of exceeding the maximum limit of $0.121 \mathrm{ppm}$ according to the regulation of the Head of the Indonesian Food and Drug Supervisory Agency Number HK.00.06.1.52.4011 in 2009

There is an effect of the use of new cooking oil and used cooking oil on fried foods wrapped in black plastic on the content of $\mathrm{Pb}$. At a hot temperature of $800 \mathrm{C}$, the temperature is medium $450 \mathrm{C}$ and cold temperature is $250 \mathrm{C}$ with a contact time of 10 minutes. The highest $\mathrm{Pb}$ content in used cooking oil with a hot temperature of $800 \mathrm{C}$ is an average of $0.881 \mathrm{ppm}$ and the lowest is for new cooking oil with a control treatment of $0.173 \mathrm{ppm}$. In foods that are packaged in black plastic packaging, there is a migration of heavy metals $(\mathrm{Pb})$ from plastic containers. $\mathrm{Pb}$ (lead) migration occurs because it is influenced by food temperature or storage and processing. The higher the temperature in these foods, the more $\mathrm{Pb}$ (lead) can migrate into fried foods.

\section{REFERENCES}

Chairunnisa, 2013 Cooking Oil Test on Fried Swords Around the Campus Syarif Hidayatullahh UIN. Jakarta Thesis

Food and Drug Supervisory Agency of the Republic of Indonesia. 2010. Food Safety Bulletin. Volume 17 / Year IX / 2010.

Ketaren, S. 2015. Introduction to Food Oil and Fat Technology. University of Indonesia Publisher, Jakarta.

Koswara, S. 2016. http://ebookpangan.com. Accessed June 18, 2018.

Ladauda A. Effect of Snack Foods on Students' Cognitive and Physical Development. Research Report. Jakarta: Pelita Harapan University, 2012

Mohammad S 2017 Food Safety for Plastic and Styrofoam Packaging Postgraduate Programs, Biomedical Nutrition Study Program FK UNDIP, Semarang, Indonesia

Novianti K. 2014. Dangers of Food Product Packaging. http: //www.bbpp-lembang. info / index.php / en / archive / article / article-pertian / 110-hazard-kemasaprodukpangan. accessed on June 2, 2018.

Riani TF, Hetty Restika Sari, and Teddy Tarudin. 2014. Influence, Process of Interaction and Occurrence of Migration of Packaging Materials to the Packaged Foodstuffs. citation: June 12, 2018. In http://ml.scribd.com/doc/132230870 